\title{
SOCIAL CAPITAL AND LIVELIHOOD DIVERSIFICATION: TOURISM ENTREPRENEURSHIP IN A REMOTE AREA OF NORTH HALMAHERA, INDONESIA
}

\author{
${ }^{*}$ Yerik Afrianto Singgalen \\ Department of Hospitality and Tourism Management, Faculty of Business Administration \\ and Communication Science, Atma Jaya Catholic University, Jakarta \\ Gatot Sasongko dan Pamerdi Giri Wiloso \\ Universitas Kristen Satya Wacana \\ Jalan Diponergoro Nomor 52-60, Salatiga, Kecamatan Sidorejo, Kota Salatiga, Jawa Tengah \\ Submitted: 10-04-2018; Revised: 09-07-2019; Accepted: 09-07-2019
}

\begin{abstract}
ABSTRAK
Artikel ini bertujuan menguraikan kapabilitas akses masyarakat terhadap modal sosial sebagai bentuk diversifikasi penghidupan masyarakat melalui kewirausahaan di bidang pariwisata. Gagasan ini berawal dari adanya optimalisasi sektor pariwisata dan ekonomi kreatif oleh pemerintah daerah sejak tahun 2017 untuk mendorong usaha kreatif di bidang pariwisata, multimedia maupun coffeeshop. Penelitian ini menggunakan metode kualitatif, sehingga proses pengambilan data menggunakan sumber data primer dan sekunder. Pengambilan data primer menggunakan teknik wawancara dan observasi, sedangkan pengambilan data sekunder menggunakan studi dokumen. Partisipan yang terlibat sebagai informan kunci penelitian ini, memiliki latar belakang mata pencaharian sebagai wirausaha di bidang jasa perjalanan wisata dan jasa pemandu wisata, jasa layanan multimedia kreatif, dan usaha Coffeeshop. Selanjutnya, proses pengamatan lapangan diselenggarakan berdasarkan kegiatan untuk mengamati proses keterlibatan pengusaha dalam kegiatan kepariwisataan daerah. Adapun, pengamatan lapangan dilakukan selama kegiatan "Torang Angkat Sampah" tahun 2017, kegiatan "Tanjung Bongo Festival" tahun 2017, kegiatan "Galela Utara Festival" tahun 2018, kegiatan "Wonderful North Halmahera" tahun 2018, kegiatan "O Molulu Ma Akere" tahun 2019. Data sekunder yang digunakan dalam penelitian ini ialah Rencana Program Jangka Menengah dari Satuan Kerja Perangkat Daerah (SKPD) Dinas Pariwisata Kabupaten Halmahera Utara setelah adanya kebijakan pengembangan ekonomi kreatif yang terjewantahkan dalam perubahan struktur birokrasi di Dinas Pariwisata Daerah. Hasil penelitian ini menunjukkan bahwa ketersediaan infrastruktur, aksesibiltias informasi dan transportasi, serta kapabilitas akses terhadap modal sosial menjadi stimulus diversifikasi penghidupan masyarakat untuk menekuni usaha pariwisata, multimedia kreatif dan coffeeshop. Melalui modal sosial, pengusaha mempererat hubungan sosial dengan terlibat aktif dalam pelbagai komunitas pariwisata. Hal ini menunjukkan bahwa pengusaha di bidang pariwisata dan industri kreatif melakukan proses bonding and bridging dengan komunitas pemerhati pariwisata daerah untuk meningkatkan konsumen sekaligus mempertahankan keberlanjutan usaha.
\end{abstract}

Kata Kunci: Diversifikasi; Kewirausahaan; Modal Sosial; Pariwisata.

*Corresponding author: Email: inggalen.yerik@gmail.com

Copyright@ 2019 THE AUTHOR(S). This article is distributed under a Creative Commons Attribution-Share Alike 4.0 International license. Jurnal Kawistara is published by the Graduate School of Universitas Gadjah Mada. 


\section{ABSTRACT}

This article aims to describe the capability of public access to social capital as a form of livelihood diversification through tourism entrepreneurship. This idea was originated from the optimization of the tourism sector and the creative economy by the local government since 2017, aiming to encourage creative entrepreneurship in tourism, creative multimedia, and coffee shop businesses. This study was conducted in a qualitative approach; thus, primary and secondary data sources were used to analyze the data. The primary data was obtained through in-depth interviews and observations, while the secondary data was obtained from document studies. In this case, the in-depth interviews were conducted with the entrepreneurs. The participants involved as key informants had various backgrounds in tourism entrepreneurship such as travel agent and tour guide service, creative multimedia service, and coffee shop business. Furthermore, field observations were done based on activities or events, aiming to observe the process of involvement of these entrepreneurs in regional tourism activities during the events of "Torang Angkat Sampah" in 2017, "Tanjung Bongo Festival" in 2017, "North Galela Festival" in 2018, "Wonderful North Halmahera" in 2018, and "O Molulu Ma Akere" in 2019. The secondary data used was the Medium Term Program Plan of the Local Government Agencies of the Regional Tourism Department of North Halmahera Regency after there was a policy of creative economy development elaborated in the bureaucratic structure changes at the Regional Tourism Department. The results show that the availability of infrastructure, accessibility of information and transportation, and the capability of access to social capital were such a stimulus for the diversification of people's livelihoods to run tourism, creative multimedia, and coffee shop businesses. Through social capital, entrepreneurs were strengthened by their social relations with various communities to have more consumers while also maintaining the business sustainability.

Keywords: Diversification; Entrepreneurship; Social capital; Tourism.

\section{INTRODUCTION}

Tourism in Indonesia has developed along with the policies to increase the quality of creative industries in the digital age of the Industrial Revolution 4.0. This shows that the development of the tourism sector contributes to the improvement of the community economy. Dritasto and Anggraeni (2013) showed various benefits of tourism activities on the economy of local communities. In the same line, Cahya et al. (2017) showed that tourism benefit to the household economy would increase significantly through active participation in tourism businesses. In addition, Chok and Macbeth (2007) showed that tourism development was such a strategy to alleviate poverty. In this development, the role of government and tourism institutions is essential in optimizing tourism development in an area (Darwis et al., 2016). Various approaches to tourism development are tailored to the potential of each region (Andyani et al., 2015). Others looks at how the local communities have became subjects of the tourism development process (Arieta, 2010). Despite illustration of various economic benefit of tourism described in these studies, there a lack of attention on the role of tourism in the diversification of community livelihood. This type of benefit is especially prevalent in the recent connection between tourism and digital development that facilitates the adoption of social capital for tourism sector.

Tourism development in a region has contributed to the livelihoods of local communities, however, resources availability and access capability in the form of capital determine the level and form of community participation in the tourism development. This shows that the readiness of a community also determines the capability of community access (Barus et al., 2013). Therefore, empowerment is a strategic step to prepare qualified human resources in the tourism sector (Brahmanto, 2013). In the context of regional tourism, Damayanti (2014) showed that capacity building programs for regional governments were an effective approach to prepare facilitators for other communities to participate in the tourism development programs. Meanwhile, Gurung and Scholz (2008) emphasize that stakeholders in the tourism sector had a very essential role in a collaboration process to achieve a sustainable tourism. Therefore, 
Harun (2014) proposes ideas to implement empowerment strategies through the development of local community-based tourism. This shows that the readiness of human resources in the field of tourism is an important aspect in achieving a sustainable tourism.

The development of regional tourism will also increase the community's income. This indicates that the tourism business can be alternative livelihoods. Hidayat (2001) previously stated that the tourism sector provided employment opportunities while also providing entrepreneurship opportunities. However, the tourism development always has consequences for the sustainability of local cultural values (Hutagalung, 2000). Therefore, an innovative village tourism development model must rely on the local culture to anticipate accul $t$ uration or assimilation (Jati et al., 2013). Efforts to anticipate acculturation can be done through local wisdom-based tourism develo $p$ ment policies (Jupir, 2013). In addition, efforts to minimize the negative impact of to $u$ rism development can also be done by involving local communities in the planning stage $(\mathrm{Li}$, 2006). Thus, the community can control the tourism development process in their respective regions (Muzha et al., 2013). This shows that there is a complexity in the regional tourism development, so that touri $\mathrm{s} \mathrm{m}$ policies and institutions play an important role to anticipate the negative im $p$ acts that are detrimental to the community when the tourism sector is developed.

In the regional tourism context in the eastern part of Indonesia, social and cultural values influence the success of a tourism development. Karsudi et al. (2010) showed that local culture could be integrated with the development approach by highlighting local wisdom. However, the management capacity of a qualified human resource-based tourism destination still needs to be optimized (Noho, 2014). Meanwhile, as time goes by and as the technology is getting more developed, there is a popularity of community-based creative tourism content (Nafila, 2013). Putra (2013) showed that creative things in the digital era were more attractive to young people. This indicates that young people play an important role in the regional tourism development to achieve sustainability.

Based on the background described earlier, it can be concluded that tourism is holistic. In the Indonesian context, cultural diversity has led to the adoption of a contextual $\mathrm{d}$ evelopment approach. The success of a chieving sustainable tourism can be observed from various perspectives. The researcher was interested in investigating the capability of community access to social capital as a form of diversification of community liveliho o ds through tourism entrepreneurship. The researcher chose eastern Indonesia as the research location, especially in the outer regency close to the Indonesia-Philippine border region such as North Halmahera Regency. The policy integration process by the Ministry of Tourism and Creative Economy with the Tourism and Creative Economy Department at the regency level was interesting to study, especially the one related to the implementation of regional creative economy development policies in relation to the capability of community access to social capital as a form of diversification of community livelihoods through tourism entrepreneurship.

North Halmahera Regency has a tourism potential that attracts tourism business investors to optimize the potential of natural, historical, cultural and marine tourisms through the construction of cottages and resorts. Singgalen showed that there were a number of foreign investors who collaborated with local communities in establishing cottage and resort businesses in North Halmahera Regency (Singgal e $\mathrm{n}$ et al, 2019a). In addition, Singgalen et al. (2019b) found that community played an important role in a digital tourism campaign. This indicates that the policy of the Ministry of Tourism and Creative Economy related to the national tourism development has changed the negative perception of the Indonesia-Philippine border region which is identical to the underdeveloped, outermost and fron tier regions (often referred as 3T (Tertinggal, Terluar, and Terdepan) in Indone- 
sia. However, participation, empowerment and collaboration between stakeholders is an essential part of tourism development in North Halmahera Regency.

The existence and role of the community in tourism development in North Halmahera Regency are manifested in the digital campaign of new tourism destinations that have not been explored. In a further investigation, the actors involved in the tourism community have diverse backgrounds, ranging from bureaucrats, politicians, academics to entrepreneurs. In the context of business fields, it can be classified as follows: travel and tour guide services, creative multimedia businesses, and coffee shop businesses. This reveals that there is a change in people's livelihoods in North Halmahera Regency which is identical to the ones based on agrarian activities to the ones based on creativity services. The shift in livelihoods occurs because there is a trend where young people love to hang out with their peers which make them a certain community, indicating the influence of social networks, norms and beliefs on these changes. Changing livelihood patterns is a form of diversification mobilized by the availability and capability of access to social capital to achieve sustainable livelihoods in the tourism sector. For these reasons, this study focuses on the capability of access to social capital as a form of diversification of community livelihoods through tourism entrepreneurship.

This research was conducted from 2016 to 2019 in Tobelo city, North Halmahera Regency, North Maluku province, Indonesia. It was done in a qualitative approach to describe the capability of community access to social capital as a form of diversification of community livelihoods through tourism entrepreneurship. The primary data was obtained through in-depth interviews with the entrepreneurs. Meanwhile, the tourism communities involved were "Generasi Pesona Indonesia di Halmahera Utara" (GenPi Halut), 'Sadar Wisata (Pokdarwis) KASBI" group, "Sahabat Laut" community, "Kaki Panjang" community, "Pengangguran Elit" community, "Gembel Elit" community, "Changa" commu- nity and "Hibualamo Kreatif" community. The participants involved as key informants had various backgrounds in the tourism entrepreneurship such as travel and tour guide service (AM), creative multimedia service (SK), and coffee shop business (NK, GT, AI, and $\mathrm{HP}$ ). Furthermore, field observations were done based on activities or events, aiming to observe the process of involvement of these entrepreneurs in regional tourism activities, such as during the events of "Torang Angkat Sampah" in 2017, "Tanjung Bongo Festival" in 2017, "North Galela Festival" in 2018, "Wonderful North Halmahera" in 2018, and "O Molulu Ma Akere" in 2019. The secondary data used was the Medium Term Program Plan of the Local Government Agencies of the Regional Tourism Department of North Halmahera Regency after there was a policy of creative economy development elaborated in the bureaucratic structure changes at the Regional Tourism Department.

\section{DISCUSSION \\ Development of Creative Industries and Tourism Businesses in North Halmahera Regency}

The development of tourism businesses in North Halmahera Regency is inseparable from the government's role, in this case the Ministry of Tourism and Creative Economy. In the period of 2016-2017, institutional bureaucratic reforms took place at the Tourism Department of North Halmahera Regency as an effort to integrate national and regional tourism policies. One of the policies that encourages the development of tourism businesses in North Halmahera Regency is the policy of developing creative economy regulated in North Halmahera Regent Regulation No. 37/2016 on Main Tasks and Structural Position Functions. Through this policy support, the regional tourism development has become more directed (Larson and Poudyal, 2012). In its development, human resource capacity in tourism has increased in terms of management of tourism destinations (Yun, 2004) and analysis of tourism markets (Edwards and Griffins, 2013). This showed that the policy 
was able to encourage an increase in the capacity of human resources in optimizing destination management through changes in the structure of tourism development by forming a creative economy in the region.

The development of information technology in the era of the Industrial Revolution 4.0 and the expansion of accessibility of transportation and communication services in North Halmahera Regency, as one of the $3 \mathrm{~T}$ regions in Indonesia, has become such a stimulus for economic growth in the tourism sector. Pearlman and Mollere (2009) showed that access to communication played an important role in marketing activities of tourism destinations so that it could attract foreign tourists to visit the area. In the context of North Halmahera, activities to market tourism destinations were still dominated by tourism observer communities including: "Generasi Pesona Indonesia di Halmahera Utara" (GenPi Halut), 'Sadar Wisata (Pokdarwis) KASBI" group, "Sahabat Laut" community, "Kaki Panjang" community, "Pengangguran Elit" community, "Gembel Elit" community, "Changa" community and "Hibualamo Kreatif" community. Institutionally, Pike and Page (2014) showed that the establishment of institutions focusing on marketing tourism destinations through creative works would make it easier for prospective tourists to access information through social media.

The policy to encourage the development of creative economy in North Halmahera Regency, as an Indonesia-Philippines border region and one of the $3 \mathrm{~T}$ regions in Indonesia, indicates the seriousness of the central government to develop the community economy equally and is such a responsive and adaptive attitude of the regional government toward this development era. Muthahhrah and Adiwibowo (2016) state that tourism was one of the development approaches that could improve the community economy. Furthermore, Ekayani et al. (2014) found that there were employment opportunities and the opportunities to increase per capita income from the tourism sector. In addition, Martina (2014) also revealed that tourism development was not only beneficial to the economy but also to the social aspects of society. Thus, the approach to tourism development is contextual depending on the local government policies to minimize various negative impacts as a consequence of development (Yachya et al., 2016). Furthermore, collaboration between stakeholders is an essential part of controlling the development process in North Halmahera Regency.

The ease of access to information through social media is a stimulus for the development of tourism businesses in North Halmahera Regency. The existence of travel service was started with the increase in consumer preferences related to the need to obtain travel services to obtain different experiences. The demand for touristy travel services is put forward by the domestic market and then developed into national to foreign markets. This is such an opportunity for entrepreneurs to gain more income from travel management and tour guide activities. In addition, the needs of domestic and foreign tourists related to travel documentation have become the opportunities for the development of creative multimedia services, while the popularity of video blogs (vlogs) by the youtubers has become a trend among the Tobelo youth of North Halmahera Regency. Furthermore, the community's need for night entertainment attractions begins to increase along with the increase in the number of coffee shops. On the other hand, the increased interest of young people in in having coffee consumption has slowly replaced the sopi (local traditional liquor) consumption. Therefore, the existence of coffee shop business is considered beneficial for the social dimension. This shows that the development of information and transportation access has made it easier for people to identify opportunities and choose profitable business fields.

The development of tourism businesses in North Halmahera Regency started with the attitude and readiness of the community in identifying opportunities and choosing the business sectors to gain economic benefits. In addition, the perceptions and behavior of en- 
trepreneurs in the tourism business in treating the tourists have also played an important role in determining the comfort level when visiting a tourist destination (Li et al, 2012). In addition, entrepreneurs in the travel and tour guide services, creative multimedia businesses, and coffee shop business have established a social network based on social norms to gain public trust in acquiring consumers as well as a strategy to maintain the business continuity.

\section{Livelihood Diversification and Access Capability to Social Capital Networks, Norms, and Trust}

Social capital helps maintain business continuity. Therefore, association and involvement in the community are the main keys to increase consumers. Entrepreneurs of travel and tour guide services, creative multimedia businesses, and coffee shop businesses do not only optimize management aspects with various product marketing strategies, but also actively participate in the tourism community as one strategy to maintain the business continuity. The social capital is the key that determines a success of a business in the early stages of development, especially for entrepreneurs (Sequeira and Rasheed, 2006). It is also widely used by migrant entrepreneurs to adapt and maintain business (Bosworth and Atterton, 2012; Hamilton et al., 2008; Kloosterman, 2010; Marger, 2001). In addition, it is also used by entrepreneurs to improve market competitiveness (Fatimah and Afifuddin, 2013). Arianto and Fitriana (2013) showed that the benefits of establishing a network based on trust, feelings to care and help each other, obedience to shared values and norms were able to solve various problems. Furthermore, Rijal and Noer (2013) found that in the community context, social capital was able to form a bond within the community to make them work proactively. This indicates that entrepreneurs used networks, norms and beliefs to increase consumers while maintaining business.

Tourism business is inseparable from the interaction between product providers and markets in the context of transactions. It involves a bonding process of forming networks (Heimtun and Abelsen, 2012). Furthermore, Handoko (2017) found finds that the benefits of social interaction between entrepreneurs and consumers (in this case tourists) could broaden their horizons or enrich their knowledge, so that knowledge innovation could be a more effective marketing strategy for achieving business sustainability (Jensen, 2010). This indicates that social networks, in addition to increasing consumer loyalty and trust, can also increase knowledge that can be converted into an effective marketing strategy. If consumers are satisfied with the product, the trust in the product and business will also increase (Christian, 2013). Chu et al. (2014) showed that consumers could stop thinking about a product or not be loyal to a particular product, so they chose not to follow others' opinions and even ignore the recommendations of their friends. Therefore, entrepreneurs in the tourism, creative multimedia and coffeeshop business took an integrated approach among marketing communications to understanding the cognitive component of consumers in "Generasi Pesona Indonesia di Halmahera Utara" (GenPi Halut), 'Sadar Wisata (Pokdarwis) KASBI" group, "Sahabat Laut" community, "Kaki Panjang" community, "Pengangguran Elit" community, "Gembel Elit" community, "Changa" community and "Hibualamo Kreatif" community in various activities such as "Torang Angkat Sampah" in 2017, "Tanjung Bongo Festival" in 2017, "North Galela Festival" in 2018, "Wonderful North Halmahera" in 2018, and "O Molulu Ma Akere" in 2019.

Using the community in the bonding and bridging process is a strategic step to get regular consumers. Larsen et al. (2004) showed that the bonding and bridging process was a relationship between social capital and social action that was able to bond the community to achieve certain goals. The capability of access to social capital allowed a livelihood diversification from agrarian to industrial works. Various facilities in running a business and the opportunity to obtain income from the tourism sector are the 
driving factors for diversification. Turner (2007) stated that social capital influenced the livelihood of small and medium-sized entrepreneurs in the eastern Indonesia. Meanwhile, the diversification of the community livelihood pattern affects the management of tourism destinations for rural governments. Sidik (2015) found that the economic opportunities through tourism business were taken seriously and accommodated to be VillageOwned Enterprises (Badan Usaha Milik Desa (BUMDes)). Furthermore, Hashimoto and Telfer (2010) stated that partnerships were the key to local economic development and imaging of regional tourism. These show that the existence of entrepreneurs in the tourism sector is a catalyst for tourism development in North Halmahera Regency area.

The form and level of participation of tour ism entrepreneurs in the tourism community can be categorized as spontaneous participation based on the active voluntary part i cipation from the process of forming and running the communities to participate in r e gional tourism activities. The tourism comm $\mathrm{u}$ nity movement is dominant to the crea tive works of market regional tourism dest i nations through social media. Hays et al. (2013) found that social media was very effective to be used as a means of marketing tourism destinations because globally, it was able to provide visual information to the public. In addition, Buhalisa and Michopouloub (2011) stated that information published on social media facilitated the access of tourism markets to the desired service products, so that the prospective tourists could choose alternative tour packages to travel based on the information obtained. The form of collaboration between entrepreneurs in the context of community with other stakeholders, such as vill a ge, district and regency governments, shows the existence of mutual relations in collaborative advantages. Thus, the development of creative industries in North Halmahera Regency has contributed to the development of creative industries in Indonesia.

\section{Contribution of the Development}

\section{of Regional Creative Industries to Indonesian Tourism}

The development of creative industries in the Indonesia-Philippines border region, in this case North Halmahera Regency, has been running as an implication of infrastructure development in the eastern Indonesia. Howe ver, the scientific contribution in the form of study on tourism and the creative indu stry, contextually in the eastern Indonesia, is still very limited. However, studies on the coffee shop business were are dominant on the feasibility analysis or aspects of the marketing strategy of small and medium businesses as well as the management of the coffee industry in the area of coffee plantations agritourism (Joehastanti, 2012; Pahlavi et al., 2014; Winantara et al., 2014). In addition, studies on creative industries (in this case the multimedia services business) are still dominant in the aspects of designing and implementing tourism information systems. Semuel (2007) examined the influence of the media (in this case the tourism information syst e $\mathrm{m}$ ) on market behavior. In addition, studies on the tourism creative industry are still dominant in technical matters (Kuncoro, 2014; Yulianto and Layona, 2015). Therefore, it can be concluded that studies on the tourism business development process and the dynamics of maintaining business are important to be explored contextually. This present study shows that the context of the creative industry and tourism business development in North Halmahera Regency is inseparable from the role of social capital which consisted of networks, norms and beliefs that the entrepreneurs use by actively participating in the community as a place for bonding and bridging to obtain consumers while also maintaining the sustainability business.

Social capital, such as networks, beliefs and values (including social and local culture), has a very essential role in the tourism entrepreneurship. The relationship between entr e preneurship and tourism can be seen from the socio-economic conditions of the comm u nity growing in the tourism sector (Dhalyana and Adiwibowo, 2013). Further- 
more, it leads to an impact on the tourism development on business opportunities and the availability of jobs related to the community (Amalia et al., 2014; Hijriati and Mardiana, 2015; Kasmiati et al., 2016; Kolopaking, 2016; Mutahharah and Adiwibowo, 2016; Rehastidya et al., 2016; Singgalen et al., 2017; Singgalen, 2016; Setiyanti and Sadono, 2011). Using the community as a means to maintain economic sustainability in the tourism sector is a part of the effective marketing strategies that considers the consumer behavior (Handriana and Wisandiko, 2017). Furthermore, Ismail and Alam (2017) showed that trust and commitment were essential in maintaining business, so that social relations became a coping strategy to deal with various possibilities that were detrimental to the business.

The development of creative industries and tourism businesses in a region contributes to the national tourism. This shows that the dynamics of entrepreneurship in remote areas actually provides an overview of the extent to which the national tourism development programs can be carried out properly. Although, the level of tourism business in North Halmahera Regency is still classified as Micro, Small and Medium-sized Enterprises (MSMEs); tourism entrepreneurial enthusiasm is manifested in the creative works of regional youth. A livelihood diversification occurs because of the popularity and business trends in the digital era introduced through partnership networks. Rezazadeh and Mahjoub (2016) found that changes in the business environment led to changes in corporate orientation that emphasized partnerships, resulting to the efforts to achieve business continuity to be pursued by mutually beneficial cooperation. It indicates that there are vulnerability factors causing changes in the pattern of livelihoods from the agrarian business to the creative industry or tourism. Asmit and Koesrindartoto (2015) explained that entrepreneurial characteristics of farmers developed because of partnerships, as well as changes in business characteristics that were highly dependent on the market demand.
In the dynamics of entrepreneurial social capital, trust and commitment are also important aspects in maintaining business. Furthermore, Ong et al. (2016) showed that consumer emotional and rational factors influenced trust and loyal behavior, so that imaging and product quality must be maintained for business continuity. In addition, the social and cultural aspects of society are also important to be integrated with the concept of entrepreneurship. Noorseha et al. (2013) explained that entrepreneurship that mobilized local socio-cultural values was able to solve problems that could not be solved by the government or other nonprofit organizations. This empathizes that the local communities have the power to develop their economy independently without having to depend on the local government. Thus, the economic independence is one form of contribution to the development of the creative and regional tourism industries to the economy in Indonesia.

One of the economic challenges of global tourism is the increasing consumer preferences for disruptive digital products. Wuryaningrat (2013) showed that the ability of a company to innovate depended on knowledge and absorptive resources, so that small and medium-sized businesses that were able to utilize the local social and cultural values and turned them into innovation capabilities could su s tain their businesses against competition. Therefore, the capability of access to social capital, the availability of resources in the form of human, natural, financial, and physical capital are important. This affects the innovation and the development of regional creative industries that were able to meet the consumer demands. Cheng and Abdul (2013) found that service quality was very important for the success of businesses in the service sector, and the perception of service quality was significantly related to the customers' satisfaction which could result in the customer loyalty. In addition, a company's image is only a partial mediator in the relationship between customer satisfaction and loyalty. This shows that the MSMEs in mobilizing local social and cultural values, as the ability of innovation, 
can transform knowledge into an effective marketing management strategy to overcome the intense competition in the disruptive era. Therefore, it can be concluded that the social capital is only one of the capitals that is important to be accessed, and it is not limited to maintain but also develop business in the midst of global tourism market competition.

\section{CONCLUSION}

This study aims to describe the capability of public access to social capital as a form of diversification of community livelihoods through tourism entrepreneurship. The results indicate that the development of the creative industry and tourism business in North Halmahera Regency is inseparable from the support of the regional government through the policy. The development of information technology, ease of access to transportation and information, and the demand for travel and digital product services have stimulated the development of tourism businesses and creative industries, resulting in a diversification of livelihoods from businesses in the agrarian sector into businesses in the tourism and creative industries. The entrepreneurs of tourism industries participate in various communities to maintain the business. In Addition, social capitals are integrated in marketing strategies to increase the number of consumers. The recommendation of this research is the need for policies that specifically mobilize the capability of tourism entrepreneurs to increase business capacity through business diversification which is able to provide employment opportunities for local communities to accelerate the process of regional economic growth in tourism sector.

\section{BIBLIOGRAPHY}

Amalia, M., Sumarti, T., and Pandjaitan, N. K. (2014). "Peluang Usaha Serta Kerja Akibat Kehadiran Wisatawan pada Komunitas Tugu." Sodality: Jurnal Sosiologi Pedesaan, 2(2): 96-102.

Andyani, N., Sukerti, N., and Masdarini, L.( 2015). "Strategi Pengembangan Agrowisata Salak di Desa Sibetan
Kabupaten Karangasem." Jurnal Bosaparis, 3(1): 1-10.

Arianto, K., and Fitriana, E. N. (2013)." Modal Sosial dalam Kemandirian Masyarakat di Bidang Kesehatan." Jurnal Kebijakan and Administrasi Publik, 17(2): 37-49.

Arieta, S. (2010). “Community Based Tourism pada Masyarakat Pesisir ; Dampaknya Terhadap Lingkungan dan Pemberdayaan Ekonomi." Jurnal Dinamika Mariti, 9(1): 71-79.

Asmit, B., and Koesrindartoto, D. P. (2015). "Identifying the entrepreneurship characteristics of the oil palm community plantation farmers in the Riau area". Gadjah Mada International Journal of Business, 17(3): 219-236.

Barus, S., Patana, P., and Afifuddin, Y. (2013). "Analisis Potensi Obyek Wisata dan Kesiapan Masyarakat dalam Pengembangan Desa Wisata Berbasis Masyarakat di Kawasan Danau Linting Kabupaten Deli Serdang." Peronema Forestry Science Journal, 2(2):137-142.

Bosworth, G., and Atterton, J. (2012). “Entrepreneurial In-migration and Neoendogenous Rural Development." Rural Sociology, 77(2): 254-279.

Brahmanto, E. (2013). "Strategi Pengembangan Wisata Gua Pindul Melalui Program Pemberdayaan Masyarakat Sekitar." Jurnal Khasanah Ilmu, 4(2): 43-47.

Buhalisa, D., and Michopouloub, E. (2011). "Information-enabled tourism destination marketing: Addressing the accessibility market." Current Issues in Tourism, 14(2): 145-168.

Cahya, A., Abdillah, Y., and Hakim L. (2017). "Partisipasi Masyarakat dalam Pengembangan Atraksi Wisata Air Terjun Kampunganyar, Kabupaten Banyuwangi." Jurnal Administrasi Bisnis (JAB), 42(1): 156-161. 
Cheng, B., and Abdul, Z. (2013). "Service Quality and the Mediating Effect of Corporate Image on the Relationship between Customer Satisfaction and Customer Loyalty in the Malaysian Hotel Industry." Gadjah Mada International Journal of Business, 15(2): 99-112.

Chok, S., and Macbeth, J. (2007). “Tourism as a tool for poverty Alleviation : a critical analysis of pro-poor tourism and implications for sustainability." Current Issues in Tourism, 10 (2): 144-164.

Christian, S. (2013). “Bauran Pemasaran (Marketing Mix) Pengaruhnya Terhadap Loyalitas Konsumen Pada Fresh Mart Bahu Mall Manado." Jurnal EMBA, 711(3): 71-80.

Chu, H., Kang, J., Lee, M., and Kim, H. (2014). "Is scissoring a metaphor for disconnecting a relationship?." Gadjah Mada International Journal of Business, 16(3): 205-221.

Damayanti, E., Soeady, M., and Ribawanto, H. (2014). "Strategi Capacity Building Pemerintah Desa dalam Pengembangan Potensi Kampoeng Ekowisata Berbasis Masyarakat Lokal (Studi di Kampoeng Ekowisata, Desa Bendosari, Kecamatan Pujon, Kabupaten Malang)." Jurnal Administrasi Publik, 2(3): 464-470.

Darwis, R. S., Resnawaty, R., Irfan, M., and Risman, A. (2016). "Peran Institusi Lokal dalam Kegiatan Pengembangan Masyarakat : Kasus Punggawa Ratu Pasundan dalam Program Desa Wisata di Desa Sukaratu Kecamatan Gekbrong Kabupaten Cianjur." Share : Social Work Jurnal, 6(1): 253-276.

Dhalyana, D., and Adiwibowo, S. (2013). "Pengaruh Taman Wisata Alam Pangandaran Terhadap Kondisi Sosial Ekonomi Masyarakat." Jurnal Sosiologi Pedesaan, 1(3): 182-199.

Dritasto, A., and Anggraeni, A. (2013). "Analisis Dampak Ekonomi Wisata Bahari terhadap Pendapatan Masyarakat di Pulau Tidung." Rela Loka (Jurnal Online Insitut Teknologi Nasional), 20(10):1-8.

Edwards, D., and Griffin, T. (2013). "Understanding tourists' spatial behaviour: GPS tracking as an aid to sustainable destination management." Journal of Sustainable Tourism, 21(4): 580-595.

Ekayani, M., Yasmin, R., Sinaga, F., and Maaruf, L. O. M. (2014). “Wisata Alam Taman Nasional Gunung Halimun Salak: Solusi Kepentingan Ekologi dan Ekonomi ( Natural tourism at Gunung Halimun Salak National Park: A solution for ecological and economic interest )." Jurnal Ilmu Pertanian Indonesia (JIPI), 19(1): 29-37.

Fatimah, M., and Afifuddin, M. (2013). "Modal Sosial Pedagang Dalam Meningkatkan Daya Saing Pasar Tradisional." Jurnal Kebijakan Dan Administrasi Publik, 17(2): 4-19.

Gurung., D., and Scholz, R. (2008). “Community Based Ecotourism in Bhutan: Expert Evaluation of Stakeholderbased Scenario." International Journal of Sustainable Development and World Ecology, 15(5): 397-411.

Hamilton, R., Dana, L.-P., and Benfell, C. (2008). "Changing cultures: an international study of migrant entrepreneurs." Journal of Enterprising Culture, 16(1): 89-105.

Handoko, I. (2017). “A Case Study of Knowledge Exchange in a Hierarchical Mechanism." Gadjah Mada Intemational Joumal of Business, 19(1): 35-57.

Handriana, T., and Wisandiko, W. H. (2017). "Consumer Attitudes Toward Advertisement and Brand,Based on the Number of Endorsers andProduct Involvement: An Experimental Stud." Gadjah Mada International Journal of Business, 19(3): 289-306. 
Harun, Z. (2014). "Model Strategi Pemberdayaan Masyarakat Melalui Pengembangan Pariwisata Berbasis Komunitas Lokal : Kasus di Kota Padang Panjang." Jurnal Antropologi : Isu-Isu Sosial Budaya, 16(1) : 99-106.

Hashimoto, A., and Telfer, D. J. (2010). “Developing sustainable partnerships in rural tourism: The case of oita, japan." Journal of Policy Research in Tourism, Leisure and Events, 2(2): 165183.

Hays, S., Page, S. J., and Buhalis, D. (2013). "Social media as a destination marketing tool: Its use by national tourism organisations." Current Issues in Tourism, 16(3): 211-239.

Heimtun, B., and Abelsen, B. (2012). "The tourist experience and bonding." Current Issues in Tourism, 15(5): 425439.

Hidayat, K. 2001. "Strategi Pengembangan Bisnis Bidang Kepariwisataan." Jurnal Ilmu Pariwisata : MiTTra, 6(1): 5865.

Hijriati, E., and Mardiana, R. (2015). “Pengaruh Ekowisata Berbasis Masyarakat Terhadap Perubahan Kondisi Ekologi, Sosial Dan Ekonomi Di Kampung Batusuhunan, Sukabumi." Sodality: Jurnal Sosiologi Pedesaan, 2(3): 146159.

Hutagalung, M. (2000). “Simbiosis Mutualisme Antara Kebudayaan dan Pariwisata." Jurnal Ilmu Pariwisata, 5(2): 43-48.

Ismail, and Alam. (2017). "Trust, Commitment and Competitive Advantage in SMEs Export Performance." Gadjah Mada International Journal of Business, 19(1): 1-18.

Jati, D., Suroso, A., and Suwandari, L. (2013). "Model Pengembangan Desa Inovatif Desa Kalisari Kabupaten Banyumas." Jurnal Sustainable Competitive Advantage (SCA), 6(1): 1-10.
Jensen, Ø. (2010). “Social Mediation In Remote Developing World Tourism Locations - The Significance Of Social Ties Between Local Guides And Host Communities In Sustainable Tourism Development." Journal of Sustainable Tourism, 18(5): 615-633.

Joehastanti, J. (2012). “Strategi Pemasaran Wisata Alam Untuk Meningkatkan Kunjungan Wisatawan Di Kawasan Wisata Kabupaten Kediri." Jurnal Revitalisasi, 1(2): 61-73.

Jupir, M. (2013). “Implementasi Kebijakan Pariwisata Berbasis Kearifan Lokal (Studi di Kabupaten Manggarai Barat)." Journal of Indonesian Tourism and Development Studies, 1(1): 28-37.

Karsudi., Soekmadi, R., and Kartodihardjo, H. (2010). "Strategi Pengembangan Ekowisata di Kabupaten Kepulauan Yapen Provinsi Papua." Jurnal Manajemen Hutan Tropika, 16(3): 148-154.

Kasmiati., Dharmawan, A., and Bratakusumah, D. (2016). "Ecotourism,livelihood System and Decoupling Sustainabilty in Wakatobi, Southeast Sulawesi." Sodality: Jurnal Sosiologi Pedesaan, 4(2): 158-164.

Kloosterman, R. C. (2010). “Matching Opportunities With Resources: A Framework For Analysing (Migrant) Entrepreneurship From A Mixed Embeddedness Perspective." Entrepreneurship and Regional Development, 22(1): 25-45.

Kolopaking, L. (2016). “International Lifestyle Migration and Social marginalization on the Tourism Village." Sodality: Jurnal Sosiologi Pedesaan, 4(1): 39-45.

Kuncoro, R. B. (2014). “Pembuatan Website Tempat Parawisata Rumah Dome New Nglepen." Speed Journal - Sentra Penelitian Engineering dan Edukasi, 11(4): 33-40.

Larsen, L., Harlan, S. L., Bolin, B., Hackett, E. J., Hope, D., Kirby, A., Nelson, A., 
Rex, T. R., and Sharphard, W. (2004). "Bonding and Bridging." Journal of Planning Education and Research, 24(1): 64-77.

Larson, L. R., and Poudyal, N. C. (2012). "Developing sustainable tourism through adaptive resource management: A case study of Machu Picchu, Peru." Journal of Sustainable Tourism, 20(7): 917-938.

Li, J., Yang, D., He, L., Tao, S., Zeng, L., and Buckley, R. (2012). "Psychological, Physiological and Behavioural Responses of Tourists to Interactions with Rhesus Macaques at Zhangjiajie, China." Journal of Ecotourism, 11(3): 202-206.

Li, W. J. (2006). “Community Decisionmaking Participation in Development." Annuals of Tourism Research, 33(1): 132-143.

Marger, M. (2001). “Social and human capital in immigrant adaptation:: The case of Canadian business immigrants." Journal of Socio-Economics, 30(2): 169170.

Martina, S. (2014). “Dampak pengelolaan taman wisata alam kawah putih terhadap kehidupan sosial dan ekonomi masyarakat." Jurnal Pariwisata, 1(2): 81-89.

Muthahharah, A., and Adiwibowo, S. (2016). “Dampak Obyek Wisata Pantai Pasir Putih Situbondo Terhadap Peluang Bekerja dan Berusaha." Sodality: Jurnal Sosiologi Pedesaan, 3(2): 102-106.

Muzha, V., Ribawanto, H., and Hadi, M. (2013). "Pengembangan Agrowisata dengan Pendekatan Community Based Tourism (Studi pada Dinas Pariwisata Kota Batu dan Kusuma Agrowisata Batu)." Jurnal Administrasi Publik, 1(3): 135-141

Nafila, O. (2013). “Peran Komunitas Kreatif dalam Pengembangan Pariwisata Budaya di Situs Megalitikum Gu- nung Padang." Jurnal Perencanaan Wilayah dan Kota, 24(1): 65-80.

Noho, Y. (2014). "Kapasitas Pengelolaan Desa Wisata Religius Bongo Kabupaten Gorontalo." Jurnal Nasional Pariwisata, 6(1): 8-21.

Noorseha, A., Yap, Ching., Sapuan, Dewi., Rashid, Z. (2013). "Social Entrepreneurial Intention among Business Undergraduates: An Emerging Economy Perspective Social Entrepreneurial Intention among Business Undergraduates: An Emerging Economy Perspective 1." Gadjah Mada International Journal of Business, 15(3): 249-267.

Ong, C. H., Salleh, S. M., and Yusoff, R. Z. (2016). "The role of emotional and rational trust in explaining attitudinal and behavioral loyalty: An insight into SME brands." Gadjah Mada International Journal of Business, 18(1): 1-19.

Pahlevi, R., Zakaria, W. A., and Kalsum, U. (2014). “Analisis Kelayakan Usaha agroindustri Kopi Luwak di Kecamatan Balik Bukit Kabulapen Lampung Barat." Jurnal Ilmu-Ilmu Agribisnis, 2(1): 48-55.

Pearlman, D. M., and Mollere, L. (2009). "Meetings, Incentive, Convention, And Exhibition Evaluation Practices: An Exploratory Study Among Destination Marketing Organizations." Journal of Convention and Event Tourism, 10(3): 147-165.

Pike, S., and Page, S. (2004). "Destination Marketing Organisations and Destination Marketing : A Narrative Analysis of the Literature." Tourism Management, 4(1): 1-26.

Putra, G. (2013). “Partisipasi Pemuda dalam Pengembangan Agrowisata di Desa Berjo, Ngargoyoso, Karanganyar." Sosialitas, 3(1): 1-12.

Rehastidya, R., Adiwibowo, S., Satria, A. (2016). "The Impact of Zoning and 
Whale Shark Attraction Tourism Toward Kwatisore Community." Sodality: Jurnal Sosiologi Pedesaan, 4(3): 265-273.

Rezazadeh, A., and Mahjoub, M. (2016). “Alliance Entrepreneurship and Entrepreneurial Orientation : The Mediating Effect of Knowledge Transfer." Gadjah Mada Intemational Joumal of Business, 18(3): 263-284.

Rijal, M., and Noer, S. (2013). "Studi Tentang Kemunculan Modal Sosial." Jurnal Kebijakan and Administrasi Publik (JKAP), 17(2): 65-75.

Semuel, H. (2007). "Pengaruh Stimulus Media Iklan, Uang Saku, Usia, dan Gender terhadap Kecenderungan Perilaku Pembelian Impulsif (Studi Kasus Produk Pariwisata)." Manajemen Pemasaran, 2(1): 31-42.

Sequeira, J. M., and Rasheed, A. A. (2006). "Start-Up and Growth of Immigrant Small Businesses: the Impact of Social and Human Capital." Journal of Developmental Entrepreneurship, 11(4): 357-375.

Setiyanti, W. D., and Sadono, D. (2011). “Impact Tourism on Off Farm Business and Employment Opportunities in Coastal Area." Sodality: Jurnal Transdisiplin Sosiologi, 5(3): 260-272.

Sidik, F. (2015). "Menggali Potensi Lokal Mewujudkan Kemandirian Desa." Jurnal Kebijakan and Administrasi Publik, 19(2): 115-131.

Singgalen, Y. (2016). “Persepsi, Modal Sosial, dan Kekuasaan Aktor dalam Perumusan dan Implementasi Kebijakan Pariwisata." Pax Humana, 3(2): 81104.

Singgalen, Y. A., Sasongko, G., Wiloso, P. G. (2019a). "Efforts to Achieve Environmental Sustainability through Ecotourism." Journal of Indonesian Tourism and Development Studies, 7(2), 1-10.
Singgalen, Y. A., Sasongko, G., Wiloso, P. G. (2019b). "Community Participation in Festival and Digital Tourism Campaign (Case of North Halmahera District, Indonesia)." Journal of Indonesian Tourism and Development Studies, 7(1): 21-31.

Singgalen, Y., Wiloso, P., Sasongko, G. (2017). "Evaluation of the Implementation of Tourism Policy." Jurnal Kebijakan and Administrasi Publik, 21(1): 82-106.

Turner, S. (2007). "Small-Scale Enterprise Livelihoods and Social Capital in Eastern Indonesia: Ethnic Embeddedness and Exclusion." Professional Geographer, 59(4): 407-420.

Winantara, I. M. Y., Bakar, A. B. U., and Puspitaningsih, R. (2014). "Analisis Kelayakan Usaha Kopi Luwak Di Bali." Jurnal Onine Institut Teknologi Nasional, 2(3): 118-129.

Wuryaningrat, N. F. (2013). “Knowledge Sharing, Absorptive Capacity and Innovation Capabilities: An Empirical Study on Small And Medium Enterprises in North Sulawesi, Indonesia." Gadjah Mada International Journal of Business, 15(1): 61-78.

Yachya, A. N., Wilopo, and Mawardi, M. K. (2016). “Pengelolaan Kawasan Wisata Sebagai Upaya Peningkatan Ekonomi Masyarakat Berbasis Masyarakat (Studi Pada Kawasan Wisata Pantai Clungup Kabupaten Malang)." Jurnal Administrasi Bisnis (JAB), 39(2): 107-116.

Yulianto, B., and Layona, R. (2015). Aplikasi Pencarian Tempat Wisata Berbasiskan GPS dengan Metode Radius dan Rating. ComTech, 6(1), 109-120.

Yun, D. (2004). “Knowledge Management in Hospitality and Tourism." Annals of Tourism Research, 31(4): 1063-1065. 